\title{
WHAT IS “PRICESAURUS MEGALODON”? REASSESSMENT OF AN ENIGMATIC PTEROSAUR
}

\author{
FELIPE LIMA PINHEIRO, CESAR LEANDRO SCHULTZ \\ Departamento de Paleontologia e Estratigrafia, IGeo, UFRGS, Cx.P. 15001, 91501-970, Porto Alegre, RS, Brasil. \\ fl_pinheiro@yahoo.com.br,cesar.schultz@ufrgs.br \\ RAFAEL GIOIA MARTINS NETO ${ }^{\dagger}$ \\ Departamento de Geologia, Campus Cariri, UFC, 63105-040, Juazeiro do Norte, CE, Brasil.
}

JOSÉ ARTUR FERREIRA GOMES DE ANDRADE

Centro de Pesquisas Paleontológicas da Chapada do Araripe, DNPM, Praça da Sé, 105, 63100-440, Crato, CE, Brasil.artur.andrade@dnpm.gov.br

\begin{abstract}
The specimens attributed to "Pricesaurus megalodon" are re-examined in order to determine whether they constitute a distinct taxon of pterodactyloid pterosaur. After careful preparation and study, the material (rostral and middle parts of two probably distinct skulls) revealed affinities with the Anhangueridae, especially with the genus Anhanguera Campos \& Kellner. The taxon "Pricesaurus megalodon" is considered here a nomen nudum for lacking distinctive diagnostic features and for being published in noncompliance with the standards of the International Code of Zoological Nomenclature.
\end{abstract}

Key words: pterosaur, Anhangueridae, "Pricesaurus megalodon”, Romualdo Formation, Araripe Basin.

RESUMO - Os espécimes atribuídos a "Pricesaurus megalodon" são reavaliados com o objetivo de se determinar se estes constituem um táxon distinto de pterossauro pterodactiloide. Após cuidadosa preparação e estudo, o material (um fragmento rostral e a parte média de, provavelmente, dois crânios distintos) revelou afinidades com Anhangueridae, em especial com o gênero Anhanguera Campos \& Kellner. O táxon "Pricesaurus megalodon" é, aqui, considerado como nomen nudum por carecer de características diagnósticas distintas e por ter sido publicado em desacordo com as recomendações do Código Internacional de Nomenclatura Zoológica.

Palavras-chave: pterossauro, Anhangueridae, “Pricesaurus megalodon”, Formação Romualdo, bacia do Araripe.

\section{INTRODUCTION}

In 1986, in an abstract of a scientific meeting, Martins Neto (1986) proposed the erection of "Pricesaurus megalodon", a new genus and species of pterodactyloid pterosaur from the Romualdo Formation of the Araripe Basin (northeastern Brazil) (Figure 1). The material comprised a rostral and a middle fragment of skull. Though it was found in two separate calcareous concretions, the material was attributed to a single individual by this author. According to Martins Neto (1986), "P. megalodon" was a crestless pterodactyloid pterosaur that had the following series of diagnostic features: (i) relative width of premaxillae in respect to maxillae; (ii) reduced intraalveolar distance; (iii) very deep premaxillary alveoli; and (iv) rounded anterior margin of the nasoantorbital fenestra. These rather imprecise characters were literally translated to English from the original abstract in Portuguese and they will be discussed in more detail below.

Kellner \& Campos (1988) analyzed the specimens and stated that the two fragments clearly represented two different individuals, the rostral fragment belonging to a larger animal.
Based on an elevation on the premaxillae of this specimen, suggesting the presence of a sagittal crest, these authors identified it as Anhanguera sp. After Kellner \& Campos (1988), the other material (the middle part of a skull) was not sufficiently well preserved and prepared to provide an accurate identification. Therefore, these authors attributed the specimen to Pterosauria indet.

Kellner \& Campos (1988) concluded that there was not sufficient evidence to support the erection of a new taxon and considered "Pricesaurus megalodon" a nomen vanum. After this, the taxon was considered "of dubious validity" by Martill (2011).

It is important to remember that, at the time of the proposition of "Pricesaurus megalodon", the knowledge about Romualdo Formation pterosaurs was very incipient, with few formally proposed species - often based on fragmentary material (see Kellner \& Tomida, 2000). In fact, the specimens referred to "P. megalodon" were never studied in detail or illustrated. Recently, this material was incorporated into the fossil collection of the Centro de Pesquisas Paleontológicas da Chapada do Araripe (CPCA, Crato, Brazil). Further preparation and careful study were 


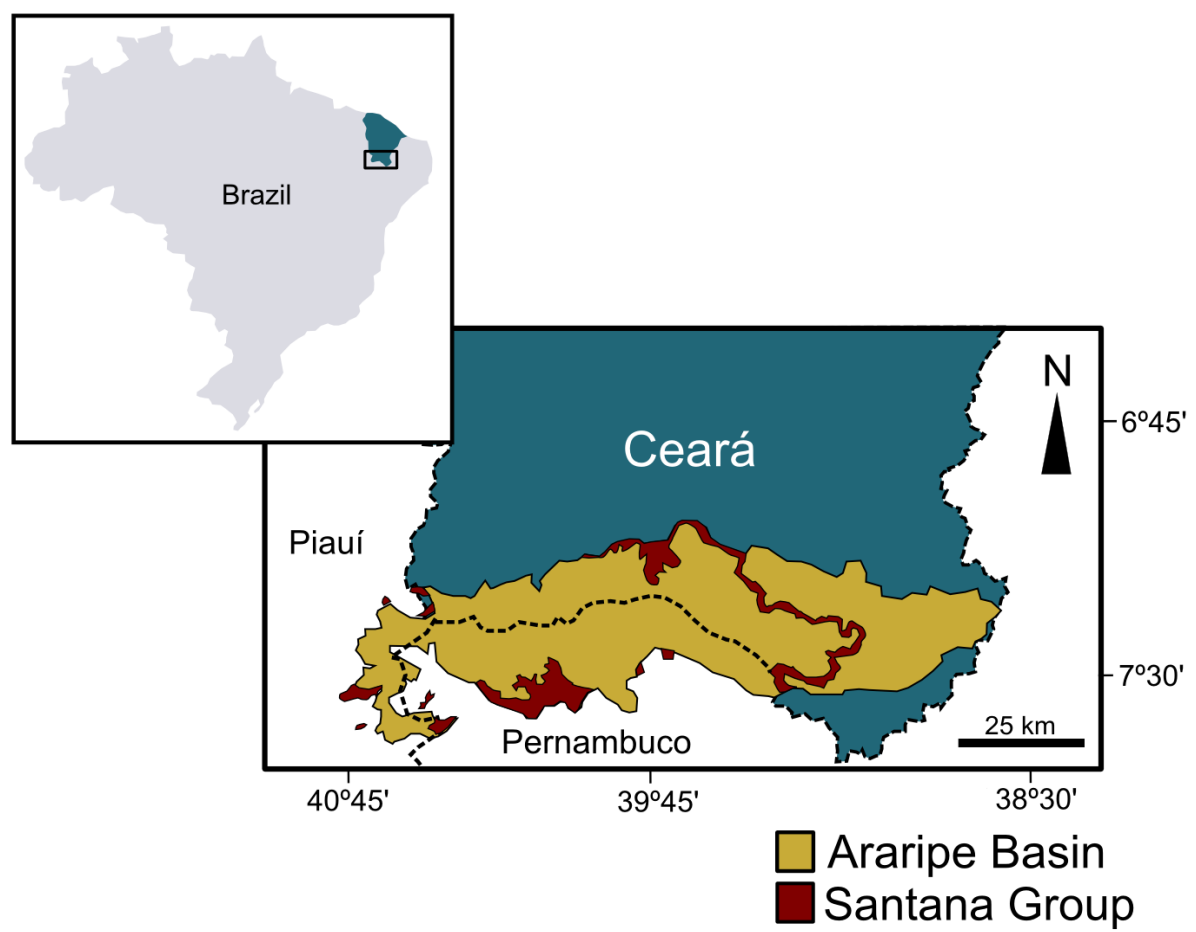

Figure 1. Location map of the Araripe Basin, northeastern Brazil. Names on the map correspond to Brazilian states.

then carried out with the intention to come to a more accurate taxonomic identification, in the light of the present knowledge of Romualdo Formation pterosaurs. The results of this work are reported in the present paper.

\section{GEOLOGICAL SETTING}

The sedimentary beds of the Romualdo Formation (Santana Group, ?Albian, Araripe Basin, northeastern Brazil) are characterized by conglomeratic sandstones followed by a transgressive sequence of green and black shales (Assine, 2007). Within the black shales, there is a layer of approximately $5 \mathrm{~m}$ in thickness, rich in carbonate concretions, with lateral continuity throughout the basin. This specific layer was probably originated during a mass-mortality event and constitutes the most fossiliferous stratum of the Araripe Basin (Mabesoone \& Tinoco, 1973; Assine, 1992, 2007; Vila Nova et al., 2011). In addition to the abundant and diversified fish fauna, the carbonate concretions of the Romualdo Formation have also yielded a number of tetrapod specimens, especially pterosaurs (see Kellner \& Tomida, 2000 for a revision).

\section{SYSTEMATIC PALEONTOLOGY}

Suborder PTEROSAURIA Kaup, 1834

Order PTERODACTYLOIDEA Plieninger, 1901

Family ANHANGUERIDAE Campos \& Kellner, 1985

Anhanguera Campos \& Kellner, 1985

Types species. Anhanguera blittersdorffi Campos \& Kellner, 1985.

Anhanguera sp.

(Figures 2A-D)
Material. Rostral end of a skull, comprising premaxillae and possibly, maxillae. Housed in the Centro de Pesquisas Paleontológicas da Chapada do Araripe under the collection number CPCA 3592 (Figure 2).

Locality, horizon and age. The specimen comes from the concretion-bearing level of the Romualdo Formation (Santana Group, Araripe Basin), being probably Albian (Early Cretaceous) in age. The exact locality is unknown.

Description. CPCA 3592 is a heavily weathered rostral end of a skull, measuring $90 \mathrm{~mm}$ in preserved length and $33 \mathrm{~mm}$ in maximum height. The outer bone surface is missing in a considerable part of the specimen but the overall shape of the bones is preserved as an internal mold of calcite. The fused premaxillae probably compose most of the specimen. In dorsal view, it is evident that the rostral expansion is spoonshaped. Eight alveoli can be distinguished on the right side of the specimen and six on the left side. Although there is no visible suture between the bones, the maxillae may contribute to the posterior part of the specimen, possibly after the seventh alveolus (there is a short diastema between alveoli VII and VIII). The rostral extremity of the specimen is eroded, exposing the internal structure of the most rostral alveoli, in which the first pair is anteriorly faced. Although the alveolar margin is shattered, making it difficult to determine precisely the alveolar sizes, a considerable difference in the diameter of some alveoli is observed. The first and second pairs are considerably smaller than the third and fourth ones. The following two pairs $\left(5^{\text {th }}\right.$ and $\left.6^{\text {th }}\right)$ are of similar size to the first and second; the $7^{\text {th }}$ and $8^{\text {th }}$ (preserved only on the right side) are slightly larger. At the level with the fourth alveolus, the premaxillae rise dorsally. This is the beginning of a sagittal crest. The dorsal margin of the crest is abraded but the structure reaches its maximum preserved height above alveolus VIII. The palatal surface is also probably 


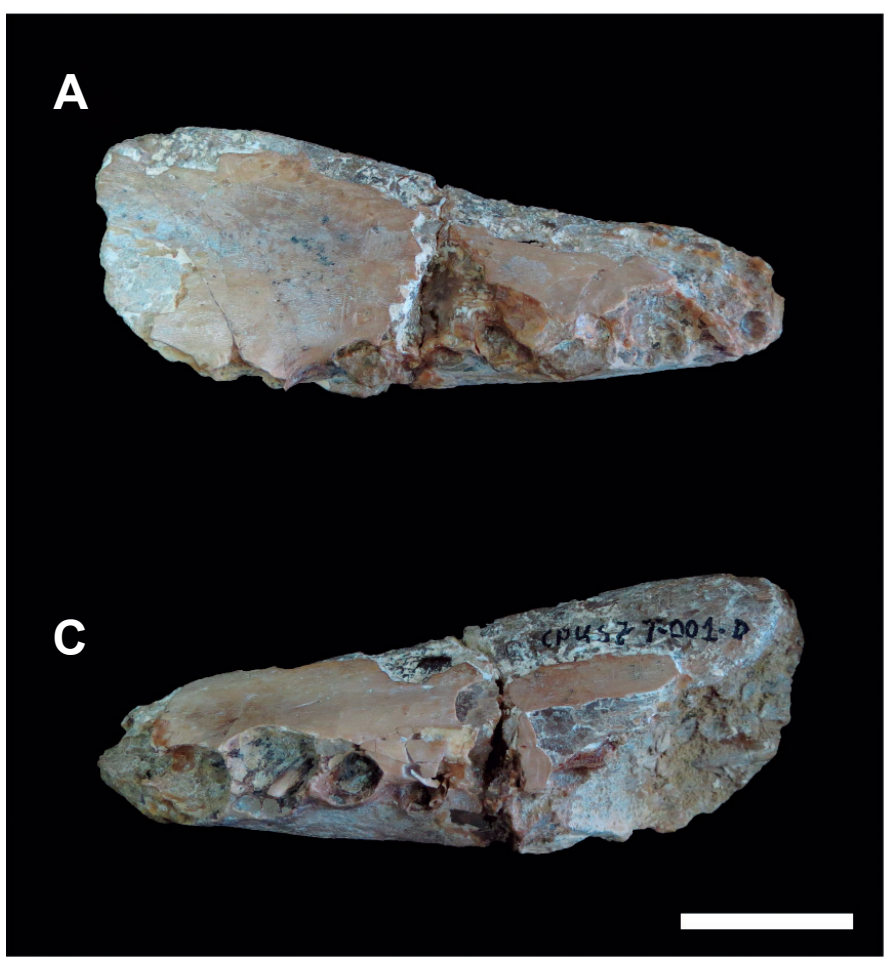

B
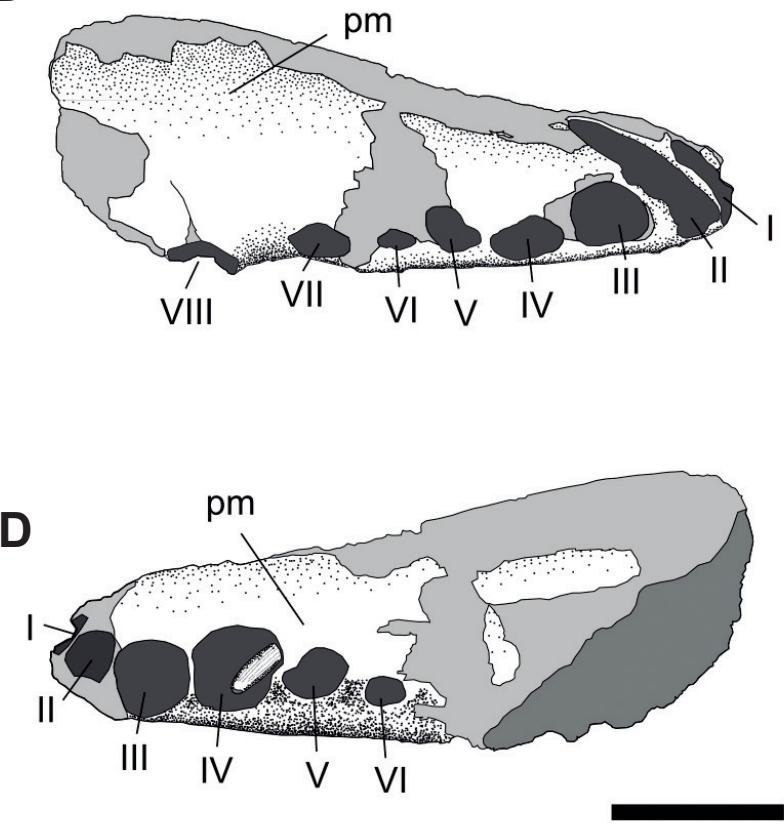

Figure 2. Anhanguera sp., specimen CPCA 3592. A-B, right lateral view; C-D, left lateral view. Abbreviations: pm, premaxilla; I-VI, dental alveoli. Scale bars $=25 \mathrm{~mm}$.

formed by the fused premaxillae and is strongly convex. In contrast to the lateral bone surface, the palate has a rough texture. The fourth alveolus in left lateral aspect bears a small conical replacement tooth, which is broken at its extremity and measures $8 \mathrm{~mm}$. The tooth enamel has well-marked longitudinal striae.

\section{cf. Anhanguera sp.}

(Figures 3A-H, 4)

Material. Middle part of a skull, comprising premaxillae, maxillae, vomers and right jugal/quadratojugal. The specimen is housed at the Centro de Pesquisas Paleontológicas da Chapada do Araripe under the collection number CPCA 3591. Locality, horizon and age. This specimen, like CPCA 3592, was also found in an unknown locality in the Romualdo Formation (?Albian), Araripe Basin.

Description. CPCA 3591 is a fragmentary pterosaur skull, composed by part of the rostrum and a considerable portion of the nasoantorbital opening, anterior to the nasals. The specimen as preserved is $180 \mathrm{~mm}$ long and $52 \mathrm{~mm}$ high. Parts of the right jugal/quadratojugal are disarticulated and lie inside the nasoantorbital fenestra, with its ventral margin standing outside the choanae, in palatal view. Although three-dimensional, with little evidence of compression, the specimen is not well preserved. The outermost bone layer is missing on a considerable portion of the left side of the skull, exposing trabecular bone filled with calcite. The venterolateral margin of the right maxilla anterior to the nasoantorbital fenestra is heavily crushed, with the shattered bone, still embedded in matrix, lying adjacent to the skull. Also, the palate anterior to the choanae is crushed and dorso-ventrally compressed. Most of the alveolar margin was not preserved, but six alveoli can be distinguished near the nasoantorbital opening, in right lateral aspect. The rostral contour of the nasoantorbital fenestra can be precisely delimited only in left lateral aspect because, on the right side of the skull, this region is badly preserved. The displacement of the right jugal suggests that the cranial bones were not completely fused, probably indicating an early to sub-adult ontogenetic stage. Nevertheless, since the original articular surfaces cannot be seen, the displacement of this bone could be also attributed to fractures. The premaxillae and maxillae are well fused, but a thin suture line between these bones is easily distinguishable both in the left and right sides of the skull. Rostrally, the skull is broken at $92 \mathrm{~mm}$ from the anterior margin of the nasoantorbital opening, whereas, caudally, most of the jugal processes of the maxillae, as well as most of the posterior process of the fused premaxillae are preserved.

Premaxillae: these bones are medially fused, with no evidence of a suture between the left and right elements. These bones form the entire preserved cranial roof as well as most of the dorsal margin of the nasoantorbital fenestra. Ventrally, thin rectilinear suture lines divide the premaxillae from the maxillae. These sutures run almost parallel to the dorsal margin of the skull. Above the nasoantorbital fenestra, the dorsal surface of the premaxillae is distinctly rounded. Towards the rostral terminus of the preserved skull, however, the dorsal margin of these bones becomes sharp, giving the skull a triangular cross-section. Although a considerable portion anterior to the nasoantorbital opening is preserved, there is no sign of a sagittal premaxillary crest. Nevertheless, the sharp anterior dorsal margin of the premaxillae may suggest that this structure was present at the missing rostral 

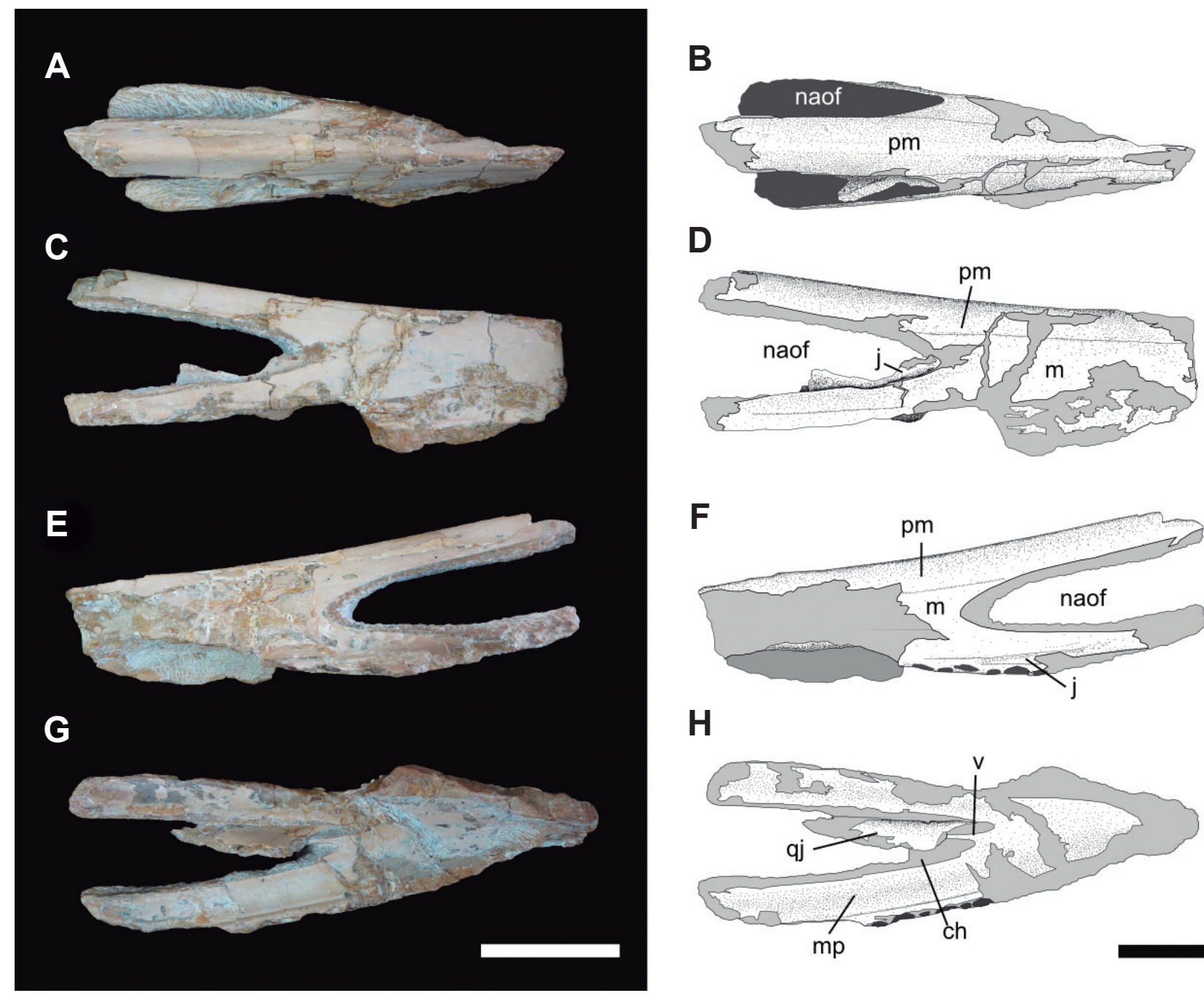

D
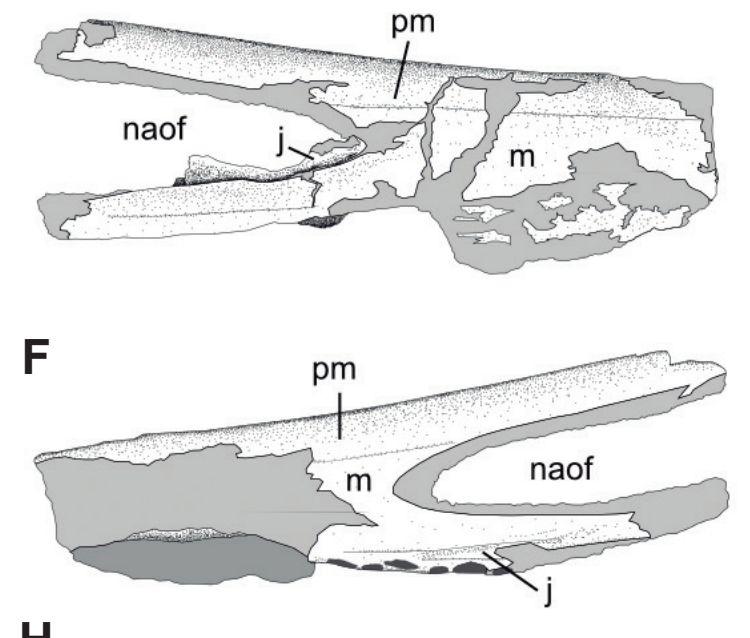

H

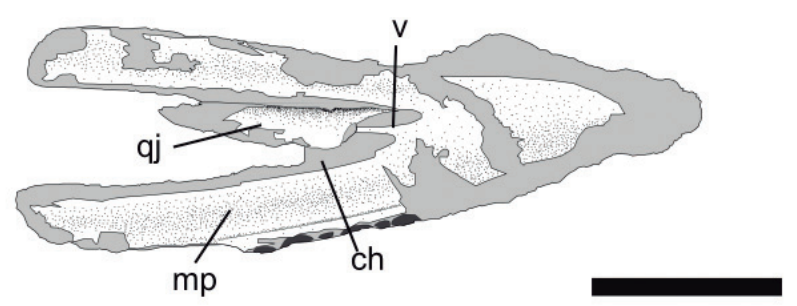

Figure 3. Cf. Anhanguera sp., specimen CPCA 3591. A-B, dorsal view; C-D, right lateral view; E-F, left lateral view; G-H, palatal view. Abbreviations: ch, choanae; j, jugal; $\mathbf{m}$, maxilla; mp, maxillary plate; naof, nasoantorbital fenestra; pm, premaxillae; qj, quadratojugal; v, vomers. Scale bars $=50 \mathrm{~mm}$.

portion of the skull, as was observed for Anhanguera araripensis by Kellner \& Tomida (2000).

Maxillae: the two maxillae are badly preserved, being crushed on the right side of the skull and lacking the outer bony layer on most of the left side, where trabeculae can be observed. The maxillae are well fused to the premaxillae but can be distinguished from these bones, as described above, by rectilinear suture lines. Short posterodorsal processes border the anteriormost dorsal boundaries of the nasoantorbital fenestrae. Most of the alveolar margin was not preserved but six small tooth sockets can be observed in left lateral aspect. Some of the alveoli are damaged, but the best preserved ones show an oval labio-lingually compressed outline about $6 \mathrm{~mm}$ in length and $4 \mathrm{~mm}$ in width. The suture lines between the caudal rami of the maxillae and the maxillary processes of the jugals apparently reach a level anterior to the rostral margin of the nasoantorbital fenestrae. In palatal view, the slightly concave palatal plates of the maxillae (see Ösi et al., 2010 for a reinterpretation of the pterosaur palate) margin the choanae anterolaterally, being the rostral limits of these openings placed anteriorly to the rostral end of the nasoantorbital fenestra. No sutures between the palatal plates of the maxillae and the vomers can be visualized. A thin groove separates the maxillary plates from the alveolar margin. This groove is interpreted by most authors as the suture between the maxillae and palatines (e.g. Campos \& Kellner, 1985; Wellnhofer, 1985; Veldmeijer, 2003a; but see Ösi et al., 2010).

Vomers: the vomers form a very slim fused element dividing the choanae medially. There is no sign of sutures between these bones and the palatal plates of the maxillae. In CPCA 3591 only the anteriormost portion of the vomers is preserved.

Jugal and quadratojugal: the fragmentary fused right jugal and quadratojugal (Figure 4) are disarticulated and lie deeply in the nasoantorbital fenestra. A probable suture between these two bones can be distinguished medially. The jugal is a flat triradiate bone, badly preserved on its medial surface. The lacrimal and postorbital processes of the jugal are broken, and the proximal portion of the maxillary process is still covered by matrix. The quadratojugal has a slim and acute process that forms the postero-ventral margin of the lower temporal fenestra. 

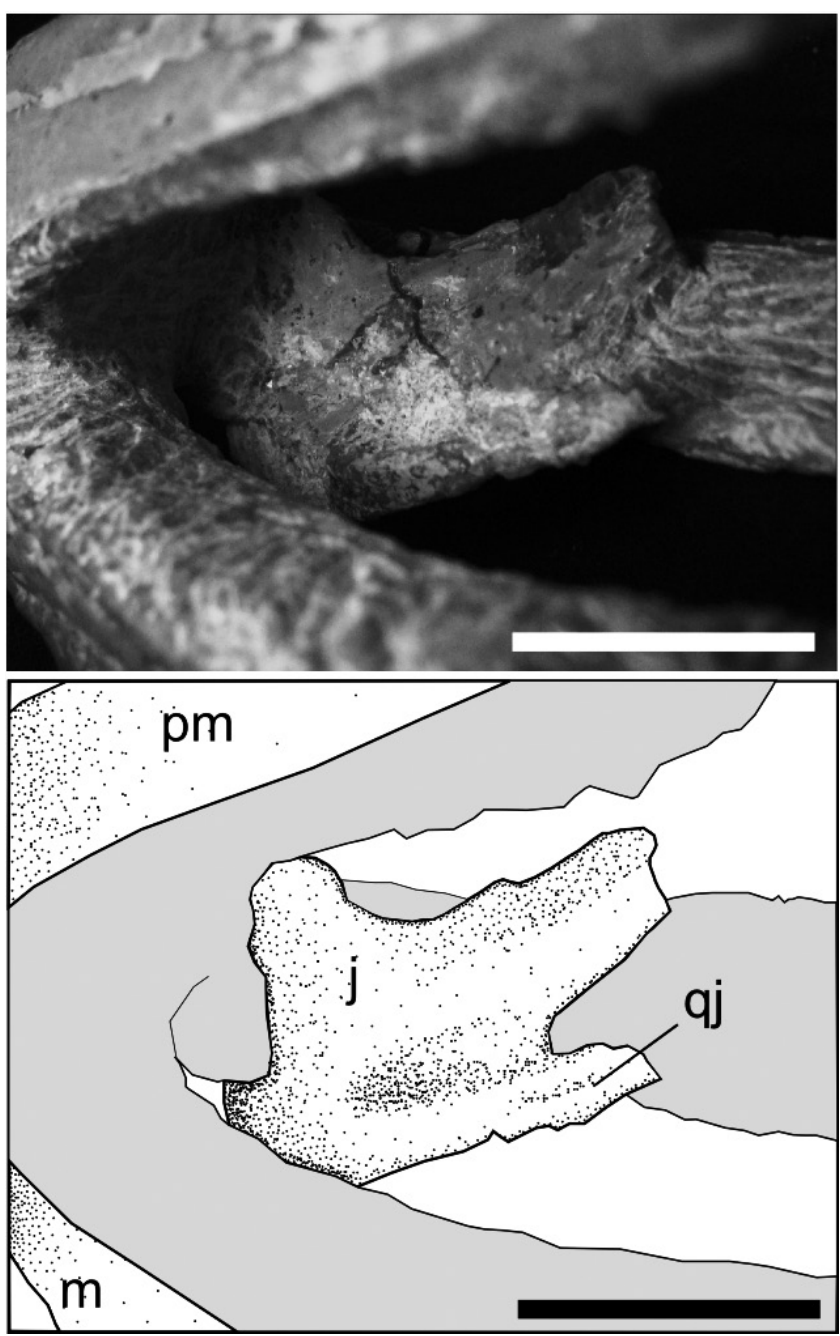

Figure 4. Detail of the right jugal and quadratojugal, displaced inside the nasoantorbital fenestra of specimen CPCA 3591. Abbreviations: j, jugal; $\mathbf{m}$, maxilla; pm, premaxilla; qj, quadratojugal. Scale bars $=$ $25 \mathrm{~mm}$.

\section{DISCUSSION AND COMPARISONS}

The taxonomy of toothed pterosaurs from the Romualdo Formation is, often, the subject of a strong debate. This issue is mainly due to the difficulty that arises when one compares the exceptionally well-preserved taxa from this sedimentary unit with the poorly preserved and extremely reworked specimens of the British Cretaceous (Rodrigues \& Kellner, 2008). During the course of the Brazilian pterosaur research, a number of taxa from the Araripe Basin were referred to English genera, like Coloborhynchus and "Criorhynchus" (Fastnacht, 2001; Veldmeijer, 2003a; Veldmeijer, 2006). A detailed approach to the issue is not an objective of the present paper. However, in order to avoid misunderstandings regarding the nomenclature that is herein utilized, it is necessary to make clear that the present study agree with the work of Rodrigues \& Kellner (2008) in that Coloborhynchus is a monospecific genus, so far restricted to the species C. clavirostris Owen, 1874 and absent in Brazilian deposits. The Brazilian species Tropeognathus mesembrinus Wellnhofer, 1987 was attributed to the genus "Criorhynchus" by Fastnacht (2001), and this genus was synonimized with Ornithocheirus by Unwin (2001). Nevertheless, due to the extremely fragmentary condition of the holotype of Ornithocheirus simus (="Criorhynchus" simus), the specimen that is usually compared with T. mesembrinus, here is regarded Tropeognathus as a valid genus, at least until more information on $O$. simus becomes available. The fact that the type specimens of $O$. simus have few characteristic morphological features was also recognized by Fastnacht (2001). It seems, therefore, unwise to synonimize a genus that is represented by complete cranial material taking into account one species is represented only by an almost uninformative fragment. The validity of Tropeognathus is in agreement with the works of Wellnhofer (1987), Kellner \& Tomida (2000) and Rodrigues \& Kellner (2008).

As mentioned in the introduction of this paper, Kellner \& Campos (1988) regarded the two specimens here described as incompatible in size, and for that reason, belonging to two different individuals. Nevertheless, using the holotype of Anhanguera blittersdorfii (MN-4805-V) as reference, we considered the sizes of the specimens compatible (i.e. the specimens probably came from animals of similar sizes) (Figure 5). On the other hand, collecting data are nonexistent, but the two specimens come from distinct calcareous concretions (this fact was originally observed by R.G.M.N., coauthor of this paper). Therefore, there is no concrete evidence to believe that they come from a single animal.

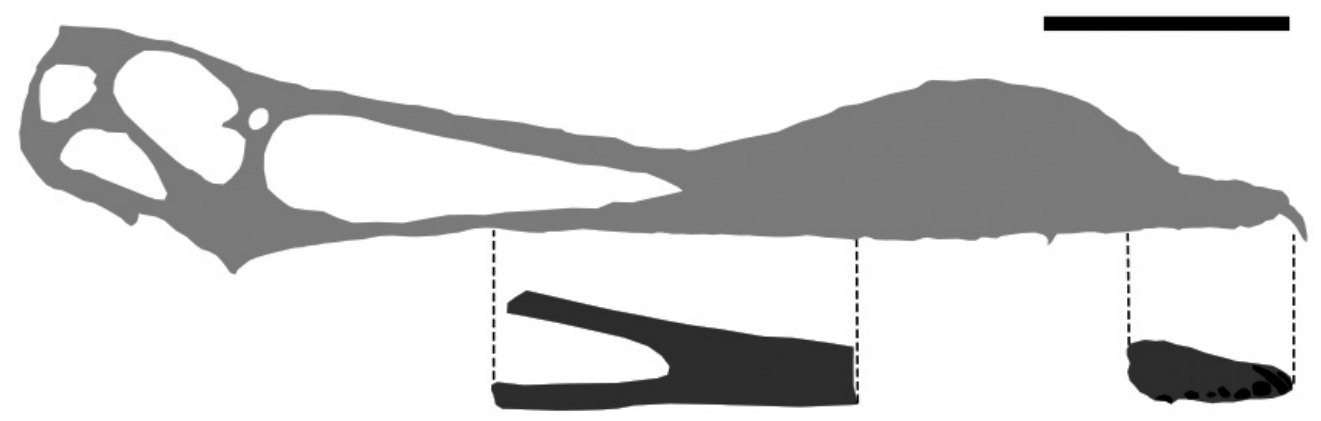

Figure 5. Comparison between the proportions of the specimens CPCA 3591, 3592 (below) and the holotype of Anhanguera blittersdorffi (above). Scale bars $=100 \mathrm{~mm}$. 
The overall shape of CPCA 3592 follows the usual morphology of anhanguerid pterosaurs like Anhanguera blittersdorffi and A. piscator Kellner \& Tomida, 2000. Comparisons are limited due to the bad state of preservation of this specimen, which obliterates features such as the exact size of the sagittal crest (this structure is dorsally abraded). In CPCA 3592, the rostral limit of the premaxillary crest is situated above the $4^{\text {th }}-5^{\text {th }}$ alveoli, a character that contrasts with the condition observed in Tropeognathus mesembrinus, since in the latter, the sagittal crest extends until the rostral tip of the skull (Wellnhofer, 1987). Cearadactylus atrox Leonardi and Borgomanero, 1985 was also revealed to bear a premaxillary crest (Vila Nova et al., 2010) (see below). Nevertheless, until more detailed data are published, comparisons of the crest of C. atrox with the one of CPCA 3592 are impossible. The comparative sizes of the teeth in CPCA 3592 (as inferred by the diameters of the alveoli) are similar to those found in A. blittersdorffi and A. piscator in the aspect that the most anterior ones represent larger teeth, the $3^{\text {rd }}$ and $4^{\text {th }}$ pairs being the largest ones (Campos \& Kellner, 1985; Kellner \& Tomida, 2000). As observed by Kellner \& Tomida (2000) for A. piscator, the $5^{\text {th }}$ and $6^{\text {th }}$ pairs are smaller than the $4^{\text {th }}$ and $7^{\text {th }}$. This is also observed in A. blittersdorffi and A. santanae (Wellnhofer, 1985), with this character being regarded as typical of the genus Anhanguera (see Kellner \& Tomida, 2000). Veldmeijer (2006) mapped alveolar and diastema sizes for a number of toothed pterosaurs from the Araripe Basin (referred by him to Coloborhynchus). A regular pattern of alveolar sizes was recognized, supporting the observations of Kellner \& Tomida (2000). It is important to remark that most of the specimens studied by Veldmeijer (2006) are attributed to Anhanguera by Kellner \& Tomida (2000), and this is the position supported herein. Also, the shattered alveolar margin of CPCA 3592 prevents from making precise measurements of the alveoli on this specimen and the tooth sockets can be only compared in their relative sizes. For instance, in CPCA 3592 , the corresponding alveoli often show different sizes on the right and left side of the specimen.

CPCA 3592 is here attributed to the genus Anhanguera, based on the presence of a premaxillary crest that does not extend to the tip of the premaxillae and on the comparative sizes of the $5^{\text {th }}$ and $6^{\text {th }}$ pairs of alveoli in respect to the $4^{\text {th }}$ and $7^{\text {th }}$ pairs. This specimen is morphologically comparable with A. blittersdorfii and A. piscator, having a size intermediate between the holotypes of these two species.

The attribution of some species we refer to as Anhanguera to the genus Coloborhynchus by some authors (e.g. Fastnacht, 2001; Unwin, 2001; Veldmeijer, 2006; Martill \& Unwin, 2012) was based mainly on a reflected palatal surface at the tip of the rostrum, exposing anteriorly the first pair of alveoli. According to those authors, this palatal reflection is present both in Anhanguera and Coloborhynchus, being much more developed in the latter. As we discussed above, we recognize Coloborhynchus as a monospecific genus, restricted to the British Cretaceous. This assumption follows the extensive revision of this taxon by Rodrigues \& Kellner (2008). Nevertheless, taking in consideration this feature, CPCA 3592 does not have a pronounced anterior reflection of the palate and, even if we followed the taxonomic framework proposed most recently by Martill \& Unwin (2012), this specimen would still be classified as Anhanguera.

CPCA 3591, in all its preserved extension, lacks a median premaxillary crest. Nevertheless, towards the rostral limits of the specimen, the dorsal margin of the premaxillae becomes sharper, suggesting that a premaxillary crest was present. Premaxillary crests restricted to the rostrum are well spread among toothed pterosaurs from the Romualdo Formation (Campos \& Kellner, 1985; Wellnhofer, 1987; Wellnhofer, 1991; Kellner \& Tomida, 2000; Veldmeijer, 2003a). Until now, only Brasileodactylus, Barbosania and Unwindia securely lacked this structure (Veldmeijer 2003b; Veldmeijer et al., 2009; Elgin \& Frey, 2011; Martill, 2011). The genus Brasileodactylus is also found in the older Crato Formation (Sayão \& Kellner, 2000). Ludodactylus sibbicki Frey, Martill \& Buchy, 2003 lacks a premaxillary crest but this taxon is, so far, restricted to the Crato Formation (Frey et al., 2003). The holotype of Cearadactylus atrox (another taxon described as crestless by Leonardi \& Borgomanero, 1985) revealed after further preparation and study by Vila Nova et al. (2010) that the premaxillae of this pterosaur also bear a crest, though there is no evidence of a similar structure on the dentary. CPCA 3591 differs from C. atrox in the aspect that, in the latter, the maxillae does not participate in the formation of the dorsal margin of the nasoantorbital fenestra whereas, in CPCA 3591, as well as, seemly, in all anhanguerids, a small posterodorsal process of the maxilla forms the anterodorsal boundary of the opening.

It is noteworthy that, following the work of Vila Nova et al. (2010), most of the diagnostic features formerly attributed to Cearadactylus atrox by Leonardi \& Borgomanero (1985) and, later, by Unwin (2002) are biased by the fact that the fossil was adulterated at the time of the first description of the species. A better understanding of Cearadactylus and its relationships within Pterodactyloidea will be possible with the redescription of the totally prepared holotype.

The position of the premaxillary crest with respect to the anterior margins of the nasoantorbital fenestrae varies considerably among anhanguerid pterosaurs (Figure 6). In some taxa, such as Anhanguera blittersdorffi and A. piscator, the crests begin above or shortly after the rostral limits of this opening (Campos \& Kellner, 1985; Kellner \& Tomida, 2000). An intermediate condition can be observed in Tropeognathus, A. araripensis and A. spielbergi, in which the crest begins at a short distance anterior to the fenestrae (Wellnhofer, 1987; Kellner \& Tomida, 2000; Veldmeijer, 2003a). In A. santanae the posterior limit of the crest is at a distance almost as long as the length of the nasoantorbital fenestra itself. Considering that the rostral sharpening of the dorsal margin of the premaxillae is indeed an indication of the presence of a sagittal crest, as observed by Kellner \& Tomida (2000) for A. araripensis, the distance between the anterior border of the nasoantorbital opening and the presumed beginning of this structure in CPCA 3591 is comparable to the condition found in A. santanae.

The taxonomic validity of the presence/absence of cranial 


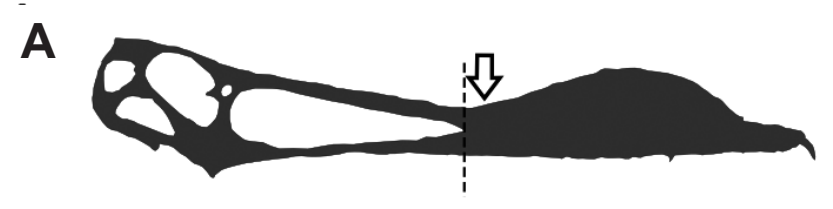

B
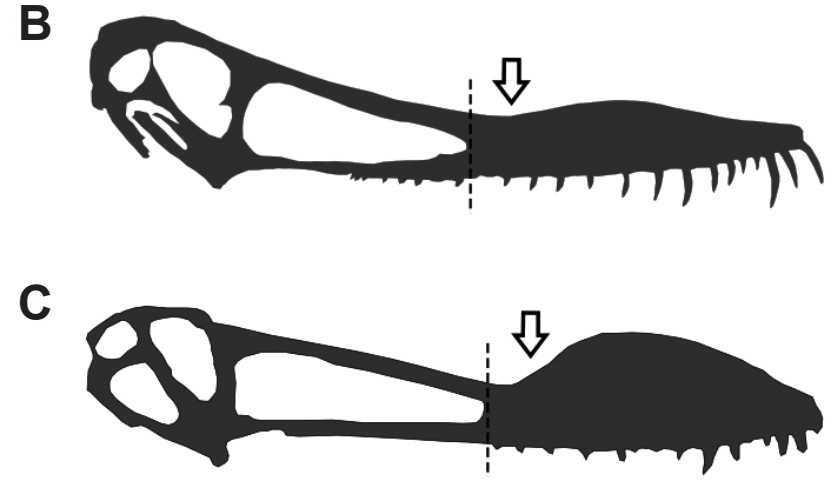

D

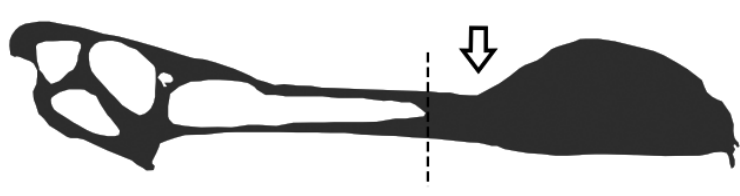

E

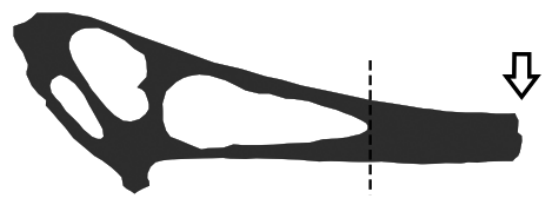

$\mathbf{F}$

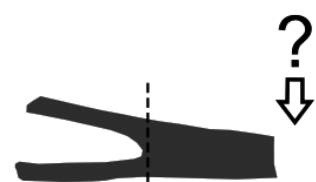

Figure 6. Position of the posterior end of the premaxillary crest with respect to the anterior margin of the nasoantorbital fenestra in some representative anhanguerids. A, Anhanguera blittersdorfii Campos \& Kellner, 1985; B, Anhanguera piscator Kellner \& Tomida 2000; C, Anhanguera spielbergi Veldmeijer, 2003a; D, Tropeognathus mesembrinus Wellnhofer, 1987; E, Anhanguera santanae (Wellnhofer, 1985); F, CPCA 3591. Not to scale.

crests and of the overall morphology of this structure in Romualdo Formation pterosaurs is not unanimously accepted. Some authors regard this structure as potentially sexually dimorphic and, thus, of limited diagnostic value (e.g. Bennett, 1992; Veldmeijer, 2006). In fact, pterosaur cranial crests were, probably, mostly display structures and a certain level of sexual dimorphism would be expected. Bennett (1992) proposed sexual dimorphism for the genus Pteranodon, taking into account the morphology of cranial crests in association with postcranial elements, such as the pelvic girdle. Nevertheless, due to the low number of pterosaur specimens with associated cranial and postcranial material in the Romualdo Formation, this issue cannot be assessed at the present time. In addition, although the presence and morphology of cranial crests have been traditionally regarded as of taxonomic value by most authors, the different pterosaur taxa from the Romualdo Formation are, in the majority of cases, also distinguishable by other, presumably, more reliable morphological features (see Kellner \& Tomida, 2000 for a revision).

The overall shape of Tropeognathus, the other genus (aside from Anhanguera and Cearadactylus) of crested toothed pterosaurs from the Romualdo Formation, the reduced number of teeth below the nasoantorbital fenestra of this pterosaur (as well as the their considerably smaller sizes) and the presence of a massive premaxillary crest that begins close to the rostral margin of the nasoantorbital opening are clearly distinguishable from the conditions observed in CPCA 3591. As discussed above, CPCA 3591 also differs from Cearadactylus because of the participation of the maxillae in the dorsal margin of the nasoantorbital fenestra. So far, only the genus Anhanguera presents morphotypes (A. santanae) where the premaxillary crest begins at a considerable distance from the nasoantorbital opening (Wellnhofer, 1991; Kellner \& Tomida, 2000). Other similarities with this genus would include the disposition of the preserved alveoli, the shape of the nasoantorbital fenestra and the contribution of the maxillae to this opening. Assuming that CPCA 3591 indeed had a premaxillary crest, this specimen is compatible with this genus and very similar to $A$. santanae. Nevertheless, CPCA 3591 differs from $A$. santanae by the extension of the choanae that, in this specimen, end at a level anterior to the rostral limits of the nasoantorbital fenestrae, although this character could be an artifact of the badly preserved state of the material (the palate is slightly compressed and the right choana is more anteriorly displaced than the left one). Therefore, we consider here CPCA 3591 as cf. Anhanguera, based on the probable presence of a premaxillary sagittal crest that begins at a considerable distance from the nasoantorbital opening.

One of the argued diagnostic features of "Pricesaurus megalodon" ("very deep premaxillary alveoli") is related to CPCA 3592. The characters "relative width of premaxillae in respect to maxillae" and "rounded anterior margins of the nasoantorbital fenestra" refer to CPCA 3591, whereas "reduced intra-alveolar distance" could be attributed to both specimens (see Martins Neto, 1986).

In CPCA 3592, the alveolar margin is shattered and the real limits of the alveoli cannot be securely defined. Some of the most anterior ones seem, superficially, unusually big and deep. Nevertheless, this is apparently an artifact of the broken outer bony layer, which exposes the internal alveolar structure. Regarding the "relative width of premaxillae in respect to maxillae", this character is rather imprecise, lacking a more accurate explanation by Martins Neto (1986). In our understanding, the proportion of these two bones does not show any major differences between CPCA 3591 and other pterosaurs such as Anhanguera araripensis, A. blittersdorffi and A. piscator, the same being true for the "rounded anterior margins of the nasoantorbital fenestra". The supposed "reduced intra-alveolar distance" is probably also biased by the badly preserved alveolar margin. In CPCA 3591, only three alveoli preserve their original outline and the other ones are artificially enlarged due to a taphonomic artifact. 
Even if "Pricesaurus megalodon" had unique diagnostic features, the erection of this taxon by Martins Neto (1986) is in unconformity with Article 8 of the International Code of Zoological Nomenclature, which states:

"8.2. Publication may be disclaimed. A work that contains a statement to the effect that it is not issued for public and permanent scientific record, or for purposes of zoological nomenclature, is not published within the meaning of the Code" (International Code of Zoological Nomenclature, 1999).

Therefore, to be considered valid, a name must be published in a vehicle that guarantees its permanence on the scientific record and its public access, with names published in meeting abstracts not being accepted for these reasons. Thus, "Pricesaurus megalodon" shall be considered a nomen nudum.

\section{CONCLUSIONS}

The specimens described as "Pricesaurus megalodon" are attributable to Anhanguera sp. (CPCA 3592) and cf. Anhanguera (CPCA 3591), with all the diagnostic features proposed originally being dubious or invalid. Because of that and since the specimens were not formally described following the guidelines of the International Code of Zoological Nomenclature, this name is considered a nomen nudum.

\section{ACKNOWLEDGEMENTS}

The initial studies of "Pricesaurus megalodon" specimens were carried out before the premature death of R.G. Martins Neto (1954-2010). Rafael, coauthor of the present paper, devoted 24 years of his life to research on Araripe Basin fossils. His extensive work on Crato Formation arthropods will, certainly, influence generations of researchers. Rafael Martins Neto's death was a great loss for Brazilian paleontology and we express here our grief and gratitude. The authors would also like to thank the American Museum of Natural History, New York, USA (in particular, M. Norell and C. Mehling), A. Kellner (Museu Nacional, Rio de Janeiro, Brazil), Á. Saraiva (Museu de Paleontologia de Santana do Cariri, Brazil), O. Rauhut (Bayerische Staatssammlung für Paläontologie und Geologie, Munich, Germany), E. Frey (Staatliches Museum für Naturkunde, Karlsruhe, Germany), R. Schoch (Staatliches Museum für Naturkunde, Stuttgart, Germany), L. Steel (The Natural History Museum, London, England) and M. Riley (Sedgwick Museum of Earth Sciences, Cambridge, England) for allowing access to fossil collections. The visit to the AMNH was funded by a Collection Study Grant (Richard Gilder Graduate School), whereas research at the BSP was possible thanks to a Deutscher Akademischer Austausch Dienst (DAAD) scholarship. Thanks are given to A. Boos for language revision. Also, the sharp revisions provided by A. Veldmeijer and A. Ösi substantially improved this paper. This work was partially funded by the Conselho Nacional de Desenvolvimento Científico e Tecnológico (CNPq) through scholarships granted to FLP and CLS. and the Instituto de Geociências of the Universidade Federal do Rio Grande do Sul, Brazil.

\section{REFERENCES}

Assine, M.L. 1992. Análise estratigráfica da Bacia do Araripe, Nordeste do Brasil. Revista Brasileira de Geociencias, 22:289300 .

Assine, M.L. 2007. Bacia do Araripe. Boletim de Geociências da Petrobrás, 15:371-389.

Bennett, S.C. 1992. Sexual dimorphism of Pteranodon and other pterosaurs, with comments on cranial crests. Journal of Vertebrate Paleontology, 12:422-434.

Campos, D.A. \& Kellner, A.W.A. 1985. Panorama of the flying reptiles study in Brazil and South America. Anais da Academia Brasileira de Ciências, 57:454-466.

Elgin, R.A. \& Frey, E. 2011. A new ornithocheirid, Barbosania gracilirostris gen. et sp. nov. (Pterosauria, Pterodactyloidea) from the Santana Formation (Cretaceous) of NE Brazil. Swiss Journal of Palaeontology, 130:259-275. doi:10.1007/s13358011-0017-4

Fastnacht, M. 2001. First record of Coloborhynchus (Pterosauria) from the Santana Formation (Lower Cretaceous) of the Chapada do Araripe, Brazil. Paläontologische Zeitschrift, 75:23-36.

Frey, E.; Martill, D.M. \& Buchy, M.-C. 2003. A new crested ornithocheirid from the lower Cretaceous of northeastern Brazil and the unusual death of an unusual pterosaur. In: E. Buffetaut \& J.M. Mazin (eds.) Evolution and Palaeobiology of Pterosaurs, Geological Society Special Publications, 217, p. 55-63.

International Commission on Zoological Nomenclature, 1999. International Code of Zoological Nomenclature, $4^{\text {th }}$ ed. The International Trust of Zoological Nomenclature.

Kellner A.W.A. \& Campos D.A. 1988. Sobre um novo pterossauro com crista sagital da Bacia do Araripe, Cretáceo Inferior do Nordeste do Brasil. Anais da Academia Brasileira de Ciências, 60:460-469.

Kellner, A.W.A. \& Tomida, Y. 2000. Description of a new species of Anhangueridae (Pterodactyloidea) with comments on the pterosaur fauna from the Santana Formation (Aptian-Albian), northeastern Brazil, Tokyo, National Science Museum, 135 p.

Leonardi, G. \& Borgomanero, G. 1985. Cearadactylus atrox nov. gen., nov. sp. Novo Pterosauria (Pterodactyloidea) da chapada do Araripe, Ceará, Brasil. Brasília, Coletânea de Trabalhos Paleontológicos, Brasília, Departamento Nacional da Produção Mineral, p. 75-80. (Série Geologia 27, Seção Paleontologia e Estratigrafia 2).

Mabesoone, J.M. \& Tinoco, I.M. 1973. Paleoecology of the Aptian Santana Formation (Northeastern Brazil). Palaeogeography, Palaeoclimatology, Palaeoecology, 14:97-118.

Martill, D.M. 2011. A new pterodactyloid pterosaur from the Santana Formation (Cretaceous) of Brazil. Cretaceous Research, 32:236243. doi:10.1016/j.cretres.2010.12.008

Martill, D.M. \& Unwin, D.M. 2012. The world's largest toothed pterosaur, NHMUK R481, an incomplete rostrum of Coloborhynchus capito (Seeley, 1870) from the Cambridge Greensand of England. Cretaceous Research, 34:1-9. doi:10.1016/j.cretres.2011.09.003

Martins Neto, R.G. 1986. Pricesaurus megalodon nov. gen. nov. sp. (Pterosauria, Pterodactyloidea), Cretáceo Inferior, Chapada do Araripe (NE-Brasil). Ciência e Cultura (suplemento), 38:757.

Ösi, A.; Prondvai, E.; Frey, E. \& Pohl, B. 2010. New interpretation of the palate of pterosaurs. The Anatomical Record, 293:243-258. doi:10.1002/ar.21053

Rodrigues, T. \& Kellner, A.W.A. 2008. Review of the pterodactyloid pterosaur Coloborhynchus. Zitteliana, B 28:219-228. 
Sayão, J.M. \& Kellner, A.W.A. 2000. Description of a pterosaur rostrum from the Crato member, Santana Formation (Aptian Albian) Northeastern, Brazil. Boletim do Museu Nacional, Nova Série, Geologia, 54:1-8.

Unwin, D.M. 2001. An overview of the pterosaur assemblage from the Cambridge Greensand (Cretaceous) of Eastern England. Mitteilungen aus dem Museum für Naturkunde in Berlin, Geowissenschaftlische Reihe, 4:189-221.

Unwin, D.M. 2002. On the systematic relationships of Cearadactylus atrox, an enigmatic Early Cretaceous pterosaur from the Santana Formation of Brazil. Mitteilungen aus dem Museum für Naturkunde in Berlin, Geowissenschaftlische Reihe, 5:239-263.

Veldmeijer, A.J. 2003a. Description of Coloborhynchus spielbergi sp. nov. (Pterodactyloidea) from the Albian (Lower Cretaceous) of Brazil. Scripta Geologica, 125:35-139.

Veldmeijer, A.J. 2003b. Preliminary description of a skull and wing of a Brazilian Cretaceous (Santana Formation; Aptian-Albian) pterosaur (Pterodactyloidea) in the collection of the AMNH. PalArch, p. 1-13.

Veldmeijer, A.J. 2006. Toothed pterosaurs from the Santana Formation (Cretaceous; Aptian-Albian) of northeastern Brazil. Utrecht University, PhD. thesis, 269 p.

Veldmeijer, A.J.; Meijer, H.J.M. \& Signore, M. 2009. Description of Pterosaurian (Pterodactyloidea: Anhangueridae,
Brasileodactylus) remains from the Lower Cretaceous of Brazil. DEINSEA, 13:9-40.

Vila Nova, B.C.; Kellner, A.W.A. \& Sayão, J.M. 2010. Short note on the phylogenetic position of Cearadacylus atrox, and comments regarding its relationships to other pterosaurs. Acta Geoscientica Sinica, 31(supp. 1):73-75.

Vila Nova, B.C.; Saraiva, A.A.F; Moreira, J.K.R. \& Sayão, J.M. 2011. Controlled excavations in the Romualdo Formation Lagerstätte (Araripe Basin, Brazil) and pterosaur diversity: Remarks based on new findings. Palaios, 26:173-179. doi: 10.2110/palo.2010.p10-072r

Wellnhofer, P. 1985. Neue Pterosaurier aus der Santana-Formation (Apt) der Chapada do Araripe, Brasilien. Palaeontographica Abteilung A, 187:105-182.

Wellnhofer, P. 1987. New crested pterosaurs from the Lower Cretaceous of Brazil. Mitteilungen der Bayerischen Staatssammlung für Paläontologie und Historische Geologie, 27:175-186.

Wellnhofer, P. 1991. Weitere Pterosaurierfunde aus der SantanaFormation (Apt) der Chapada do Araripe, Brasilien. Palaeontographica Abteilung, A, 215:43-101.

Received in March, 2012; accepted in August, 2012. 